\title{
CHEMERIN IS AN INDISPENSABLE PRE-TREATMENT PREDICTOR OF SOFOSBUVIR, PEGYLATED INTERFERON- ALPHA AND RIBAVIRIN OUTCOMES IN CHRONIC HEPATITIS C EGYPTIAN PATIENTS
}

\author{
Marwa O. El-Derany ${ }^{1 *}$, Al-Aliaa M. Sallam ${ }^{1,2}$ \\ ${ }^{1}$ Department of Biochemistry, Faculty of Pharmacy, Ain Shams University, Cairo, \\ Egypt. \\ ${ }^{2}$ Department of Biochemistry, School of Pharmacy and Pharmaceutical industries, Badr \\ University, Badr City, Cairo, Egypt.
}

\section{*Corresponding author: marwa.omar@pharma.asu.edu.eg}

\begin{abstract}
Chronic hepatitis $\mathrm{C}(\mathrm{CHC})$ treatment modalities dramatically evolve, however some patients still suffer treatment failure with sever aggressive side effects. Accordingly personalizing antiviral treatment becomes an urgent cornerstone in treatment path. Inflammation is one of the hallmarks of viral infection. Besides it is one of the main factors interfering with drug response. Accordingly, this study focused on studying some inflammatory markers interfering with antiviral response in different CHC patients.
\end{abstract}

A cohort of 157 genotype 4 (G4) Egyptian CHC patients treated with sofosbuvir (SOF), pegylated interferon-alpha-2a (Peg-IFNa-2a) plus ribavirin (RBV) were enrolled. Single nucleotide polymorphism (SNP) within chemerin gene (rs17173608) was analyzed by quantitative real-time PCR (qRT-PCR). Serum chemerin, serum IL-6 and serum alpha-fetoprotein (AFP) were analyzed by enzyme-linked immunosorbent assay (ELISA).

Fibrosis grade, serum AFP, serum IL-6 and serum chemerin levels were found to be significant univariant predictors of SOF, Peg- IFNa-2a and RBV response at $(\mathrm{p}<0.01)$. Moreover, G/G Chemerin (rs17173608) genotype was also proved to be associated with treatment failure $(\mathrm{OR}=17.067-95 \% \mathrm{CI}=6.684-43.575-\mathrm{p}<0.001)$ in Egyptian CHC G4 patients. Combining all predictors in Multiple stepwise regression analysis concluded that higher serum chemerin levels and G/G Chemerin rs17173608 genotype formulated the strongest predictive model with a significant prediction capacity expressed by area under the receiving operating curve (AUROC) $0.881(95 \%$ $\mathrm{CI}=0.832-0.931)$ with specificity of $77.1 \%$, sensitivity of $80.2 \%$ and accuracy of $78.9 \%$. 
Chemerin is a vital pretreatment predictor of anti-HCV drug response as it accurately predicts SOF, Peg- IFN $\alpha-2$ a and RBV different outcomes in naïve Egyptian CHC G4 patients.

Keywords: Chronic hepatitis C, Inflammation, Chemerin, Genotype 4, Single nucleotide polymorphism, Sofosbuvir.

\section{Introduction}

Hepatitis $\mathrm{C}$ virus (HCV) is one of the greatest public health threats worldwide. Left untreated chronic hepatitis $\mathrm{C}(\mathrm{CHC})$ silently progress into liver cirrhosis, liver failure and hepatocellular carcinoma (HCC) (Ghany et al., 2009). Although HCV has six genotypes, genotype 4 (G4) constitutes 90\% of HCV infections in Egypt (Desbois and Cacoub, 2017). Over the past years, more so recently, treatment modalities for $\mathrm{CHC}$ have grown exponentially. There has been combination in treatment of injectable interferon (IFN) with ribavirin (RBV) with oral, direct-acting antivirals (DAAs). In particular, regimens using sofosbuvir (SOF) lead to cure rates close to $80-90 \%$ besides shortening the duration of treatment to 12-24 weeks (Gane et al., 2017). Hence, SOF showed remarkable improvements in sustained virologic response (SVR) and treatment success. However, there is still percent of failure with severe side effects are precipitated in some patients.

Viral replication and its persistence induce an intense inflammatory response that results in $\mathrm{CHC}$ progression. This aggravates immune response eliciting systemic and local immune activation accompanied by exploiting an array of cytokines and chemokines (Costantini et al., 2010; Fallahi et al., 2012). The downregulation of inflammatory biomarkers in association with HCV eradication after antiviral therapy is still unclear. Alongside, recent studies showed a disruption in the milieu of soluble inflammatory mediators associated with drug resistance and viral non response (NR) (Menezes et al., 2017). This suggestes that the inflammatory changes might have a vital role in antiviral treatment failure.

Chemerin is an immune-metabolically and chemotactically active adipokine. Its gene termed retinoic acid receptor responder 2 (tazarotene-induced gene 2) encodes for chemerin protein which is associated with obesity and inflammatory diseases (Bozaoglu et al., 2007). Chemerin receptors are expressed in the liver which proved that chemerin may be relevant in liver physiology and pathophysiology (Stojek, 2017). Chemerin has a chimeric nature; having pro-inflammatory properties. The pro-inflammatory action is exerted by activating and recruiting natural killers (NK) cells and macrophages into inflamed tissue (Moretta et al., 2008). Chemerin was found to be markedly expressed in CHC liver (Kukla et al., 2014). In the same line other study recorded that platelet counts and total bilirubin levels are associated with serum chemerin levels in patients with HCC (Imai et al., 2014). Interestingly, minor G allele of the chemerin rs17173608 polymorphism was significantly associated with metabolic syndrome in Egyptian patients (Mehanna et al., 2016). However, to the best of our knowledge chemerin association with treatment outcomes in CHC patients hasn't been studied yet. 
Hence, the present study aimed at analyzing circulating levels of inflammatory cytokines serum chemerin, serum IL-6 as well as exploring the possible association of Chemerin (rs17173608) single nucleotide polymorphism (SNP) and fibrosis score, serum alfa feto-protein (AFP) along with other metabolic factors with triple therapy (SOF, Peg-IFNa-2a and RBV) treatment outcome in CHC G4 Egyptian patients.

\section{Subjects and Methods}

\subsection{Study design \& Therapeutic protocol}

A cohort of 157 G4 patients were recruited from Dr. Yassin Abdel Ghaffar Center for liver diseases and researches, Cairo, Egypt and Dr Nadia Al-Ansari's private clinic, Cairo, Egypt. Patients were assigned to receive triple anti HCV therapy, peg-IFN $\alpha-2 \mathrm{a}, \mathrm{RBV}$ and SOF, according to current guidelines, in the doses $180 \mu \mathrm{g}$ (peg IFN $\alpha-$ 2a)/week, 800-1000 mg RBV given orally daily based on body weight and $400 \mathrm{mg}$ of SOF orally daily. The duration of treatment was 12 weeks. Inclusion criteria were based on patient's adherence to treatment whereas patients were asked to stick to the followup visits and 6 months after end of the treatment those failed to adhere to treatment schedule were excluded from our study. Moreover, exclusion criteria involve any viral co-infection, alcohol consumption, autoimmune diseases, diabetes and any hematological diseases.

The study was approved by the Committee on Medical Ethics of ASUH, and informed consent was obtained from each patient. The study was carried out in accordance with the regulations of the Declaration of Helsinki.

Histopathological data were collected from liver biopsies specimens whenever possible and were scored using the METAVIR system as follows: F0, no fibrosis; F1, portal fibrosis; F2, peri-portal fibrosis or rare portal - portal septa; F3, fibrous septa with architectural distortion; F4, definite cirrhosis. All biopsies were evaluated and scored by the same pathologist.

Patients were further classified into two groups according to their response. First was SVR group: patients who were HCV RNA negative more than 12 weeks after the end of therapy. Second was NR group those patients never become HCV RNA negative.

Diagnosis of HCV infection was made by the persistent presence of $\mathrm{HCV}$ antibodies that determined by third generation enzyme-linked immunosorbent assay (ELISA) (diasorin) and serum HCV RNA was detected by using real time polymerase chain reaction (RT-PCR) (Taqman Roche Amplicon assay).

\subsection{Biochemical and Virological studies}

For all 157 patients, a baseline serum sample, collected before starting antiviral therapy, was separated and stored at $-80^{\circ} \mathrm{C}$ until used. Biochemical studies were performed on a fasted sample and included liver function tests and blood sugar. Hematological tests were performed. All spectrophotometric measurements were carried out using a UV/visible 1650 spectrophotometer (Shimatzu, Lenexa, KS, USA). 
Moreover, serum IL-6 levels were determined by ELISA using commercially available kits (DRG International, Inc., USA). Also, serum AFP was quantified by EIA using available kit (Human CanAg AFP, Fujirebio, Diagnostic, Inc. Goteborg, Sweden).

Virological studies for the presence or absence of $\mathrm{HCV}$ antibodies was detemined by third generation ELISA (DiaSorin). All ELISA procedures were done by Hyprep Automated ELISA system (Hyperion Inc, Miami, FL) according to the manufacturer's instructions. Serum HCV RNA was detected by using qRT-PCR (TaqMan Roche Amplicor ${ }^{\mathrm{TM}}$ Assay) (Heid et al., 1996).

\subsection{Viral genotyping}

Serum sample was used for HCV genotypes determination by a reverse hybridization assay (VERSANT HCV Genotype 2.0 Assay (LiPA); Siemens, Tarrytown, NY USA). Amplification of the 5'UTR and core region of the HCV RNA is first generated by RT-PCR then hybridized to immobilized oligonucleotide probes. The probes are specific for the 5'UTR and core region of different genotypes.

\subsection{DNA extraction}

A whole blood sample was collected too for routine hematological tests and genomic DNA extraction with QIAamp DNA Mini Kit protocol (QIAGEN, Santa Clarita, CA) according to the manufacturer's instructions. Where DNA samples were further quantitated and assessed for purity using the NanoDrop ${ }^{\circledR}$ (ND)-1000 spectrophotometer (NanoDrop Technologies, Inc. Wilmington, USA).

\subsection{Analyses of SNP at chemerin gene}

This was carried out by the use of custom TaqMan® SNP assays with reagents constitutes a ready-to-use system for the detection of chemerin rs17173608 gene using assays-by-Design supplied by Applied Biosystems International ABI; Applied Biosystems, Foster City, CA) according to the manufacturer's instructions. Putative departures of Hardy-Weinberg Equilibrium were calculated by using the software Haploview 4.1. (Ladero et al., 2012).

\subsection{Statistical analysis}

IBM SPSS statistics (V. 22.0, IBM Corp., USA, 2013) was used for data analysis. Data were tested for normal distribution using Shapiro-Wilk test. Comparison between continuous parametric data were done using analysis of variance (ANOVA) any skewed data were further analyzed by Kruskal-Wallis and Mann-Whitney U test. The associations between categorical variables were evaluated using a Pearson chisquared test and a chi-squared test for linear trend. Simple and multiple binary logistic regression were performed with forward approach. The area under the receiving operating curve (AUROC) indicated the prediction capacity of this analysis. The results were reported as odds ratio (OR) and their $95 \%$ confidence intervals (CIs). A difference of $\mathrm{p}<0.05$ was considered significant. 


\section{RESULTS}

Baseline biochemical and clinical characteristics of the whole study population are presented in Table (1). 91\% of the patients were classified as SVR and 9\% were classified as NR.

Univariate analysis showed that higher serum IL-6 was associated with treatment failure $(\mathrm{OR}=3.09-95 \% \mathrm{CI}=1.391-10.959-\mathrm{p}=0.01)$. Lower serum AFP was found to be associated with SVR if compared to NR (OR=0.114- 95\% CI $=0.044-0.298$ $\mathrm{p}<0.001)$ Serum chemerin was also found to be a strong predictor of SVR if compared to NR (OR=4.105- $95 \% \mathrm{CI}=2.026-8.318-\mathrm{p}<0.001)$.

Table 1: Baseline clinical characteristics of $\mathrm{HCV}$-infected patients included in the present study.

\begin{tabular}{|l|l|l|l|l|}
\hline Characteristics & SVR & NR & Pvalue & $\begin{array}{l}\text { Statistics } \\
\text { (univariate })\end{array}$ \\
& $(\mathrm{n}=143)$ & $(\mathrm{n}=14)$ & & OR(95\%CI) \\
\hline Age mean \pm SD (years) & $49.4 \pm 10$ & $51.4 \pm 4.9$ & - & \\
\hline Gender distribution[n(\%)] & & & - & \\
\hline Male & $56(39)$ & $5(35.7)$ & & \\
\hline Female & $87(61)$ & $9(64.8)$ & & \\
\hline BMI, mean \pm SD, kg/m2 & $29.2 \pm 4.9$ & $29.7 \pm 5.1$ & - & \\
\hline Viral load median, IU/mL & $1,552,000$ & $2,630,381$ & - & \\
\hline aAST median $(\mathrm{range}), \mu \mathrm{kat} / \mathrm{L}$ & $1.66(4.65)$ & $1.44(4.22)$ & - & \\
\hline bALT median $(\mathrm{range}), \mu \mathrm{kat} / \mathrm{L}$ & $2.04(6.22)$ & $1.7(5.63)$ & - & \\
\hline Albumin mean $\pm \mathrm{SD}, \mathrm{g} / \mathrm{L}$ & $39 \pm 5$ & $39 \pm 5$ & - & \\
\hline Bilirubin mean $\pm \mathrm{SD}, \mu \mathrm{mol} / \mathrm{L}$ & $13.68 \pm 50.45$ & $15.39 \pm 44.46$ & - & \\
\hline Hemoglobin mean $\pm \mathrm{SD}, \mathrm{g} / \mathrm{dL}$ & $13 \pm 6.1$ & $13.5 \pm 7$ & - & \\
\hline Platelets mean $\pm \mathrm{SD}, 109 / \mathrm{L}$ & $191 \pm 61$ & $166 \pm 54$ & - & \\
\hline cTLC mean $\pm \mathrm{SD}, 109 / \mu \mathrm{L}$ & $5.8 \pm 1.8$ & $6.3 \pm 1.5$ & - & \\
\hline eAFP mean $\pm \mathrm{SD}, \mathrm{ng} / \mathrm{mL}$ & $9.3 \pm 8.9$ & $24.8 \pm 24.4$ & 0.001 & $0.114(0.044-0.298)$ \\
\hline IL-6 $(\mathrm{pg} / \mathrm{mL})$ & $6 \pm 0.5$ & $11 \pm 0.4$ & 0.01 & $3.09(1.391-10.959)$ \\
\hline Chemerin $(\mathrm{ng} / \mathrm{mL})$ & $291 \pm 16$ & $3578 \pm 11$ & 0.001 & $4.105(2.026-8.318)$ \\
\hline
\end{tabular}

a AST, aspartate aminotransferase; b ALT, alanine aminotransferase; c TLC, total leukocyte count;

d HOMA-IR, homeostatic model of insulin resistance; e AFP, alpha feto protein; NR, non-responders; SVR, sustained virological responders; N, number of samples; OR, odds ratio; 95\%CI Confidence Interval.

Regarding the Liver histology, it was found that lower fibrosis grades models F1 and F2 were significantly associated with SVR group (2.532- 95\% CI =1.396-4.591) when compared to NR group. Relating chemerin genotypes with treatment responses it 
showed that chemerin rs17173608 was significantly predicting treatment outcomes. Whereas, the presence of chemerin $\mathrm{rs} 17173608 \mathrm{G} / \mathrm{G}$ genotype was powerfully related to NR $(O R=17.067-95 \%$ CI $=6.684-43.575-\mathrm{p}<0.001)$ as shown in Table 2.

Table 2: Association analysis of different fibrosis grades and chemerin gene polymorphisms with the response to antiviral treatment.

\begin{tabular}{|c|c|c|c|c|}
\hline Characteristics & $\begin{array}{l}\text { SVR } \\
(n=143)\end{array}$ & $\begin{array}{l}\mathrm{NR} \\
(\mathrm{n}=14)\end{array}$ & Pvalue & $\begin{array}{l}\text { Statistics (univariate) } \\
\text { OR }(95 \% \mathrm{CI})\end{array}$ \\
\hline Fibrosis stage, $[\mathrm{n}(\%)]$ & & & 0.002 & $2.532(1.396-4.591)$ \\
\hline F0 & $37(26)$ & 0 & - & \\
\hline $\mathrm{F} 1$ & $23(16)$ & 0 & - & \\
\hline $\mathrm{F} 2$ & $27(19)$ & $2(14.2)$ & - & \\
\hline F3 & $33(23)$ & $6(43)$ & - & \\
\hline $\mathrm{F} 4$ & $23(16)$ & $6(43)$ & - & \\
\hline Chemerin rs17173608 $[\mathrm{n}(\%)]$ & & & \multicolumn{2}{|c|}{ Chi2 $=23.812 p<0.001$} \\
\hline \begin{tabular}{l|l}
$\mathrm{G} / \mathrm{G}$ \\
\end{tabular} & $5(3)$ & $5(36)$ & $<0.001$ & $15.3(3.7-62.8)$ \\
\hline $\mathrm{G} / \mathrm{T}$ & $43(30)$ & $5(36)$ & & \\
\hline $\mathrm{T} / \mathrm{T}$ & $95(67)$ & $4(29)$ & & \\
\hline
\end{tabular}

OR, odds ratio; 95\%CI Confidence Interval; SVR: sustained viral response; NR: non response; Chi-square test for genotype distribution.

All significant variables were included in the multiple logistics regression analysis after controlling for the confounders. Our results found showed that higher serum chemerin levels, the presence of chemerin rs17173608 G/G genotype could successfully differentiate SVR from the NR group. The predictive capacity of the final model was quite good as indicated by the AUROC curve $0.881(95 \% \mathrm{CI}=0.832-0.931)$ with specificity of $77.1 \%$, sensitivity of $80.2 \%$ and accuracy of $78.9 \%$ as shown in figure 1 .

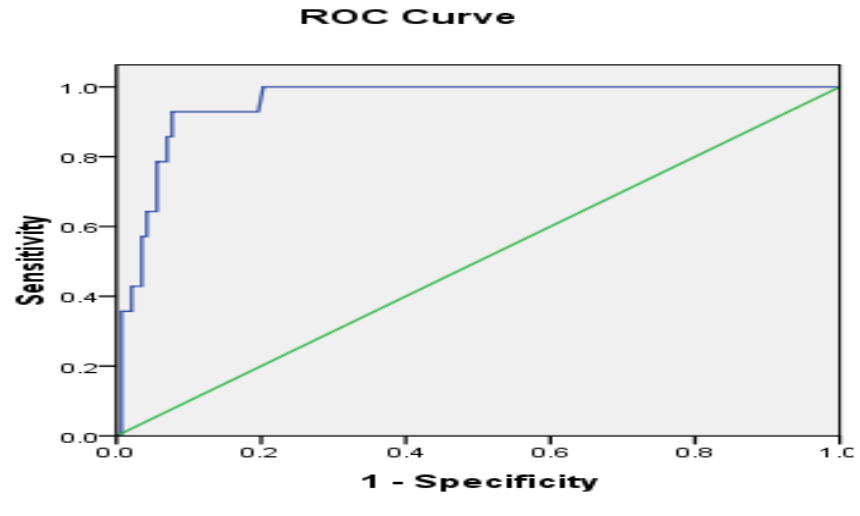

Diagonal segments are produced by ties.

Figure 1. ROC (receiving operating curve) of the multivariate analysis. AUROC was $0.881(95 \% \mathrm{CI}=0.832-0.931)$ 


\section{DISCUSSION}

Depending on different host and viral factors patients experience variable treatment responses either treatment success with SVR or treatment failure (Ghany et al., 2009). Refining these pre-treatment predictors would definitely personalize therapeutic options, increasing rates of success and avoiding serious adverse effects and intolerability experienced by several patients (Cavalcante and Lyra, 2015).

Chemerin, an adipokine, is a chemoattractant protein mainly expressed in white adipose tissues and liver (Hart and Greaves, 2010). Previous studies demonstrated the pleiotropic role of chemerin in diverse biological processes including inflammation (Weigert et al., 2010), lipid metabolism and insulin resistance (Roman et al., 2012) and immune response regulation (Habib et al., 2017). Chemerin is well known for its chemotactic activity. It has chemokine-like receptor 1 (CMKLR1) which is expressed on macrophages and NK cells and respond to chemerin (Zabel et al., 2014). Inflammatory mediators like lipopolysaccharide (LPS) and tumor necrosis factor $\alpha$ (TNFa ) strongly induce adipocyte chemerin synthesis (Bauer et al., 2011). Surprisingly, it was proved that G/G genotype of chemerin (rs 17173608) was associated with higher serum levels of chemerin (Mehanna et al., 2016). Whereas, higher serum chemerin levels are found to be associated with CHC progression (El-Mesallamy et al., 2011; Ali et al., 2018). However, chemerin relation to treatment response of CHC hasn't been elucidated yet. That's why we sought to study the effect of Chemerin (rs17173608) genetic variants in predicting treatment outcome in CHC patients. Our results showed strong association between $\mathrm{G} / \mathrm{G}$ genotype and increased serum chemerin levels with treatment failure. This also highlight the possible role played by inflammation in treatment failure of CHC patients. Conforming the possible association between inflammation and failure of antiviral response, this study along with a previous one found a possible association with increased serum IL-6, a well-known proinflammatory cytokine (Tanaka et al., 2014), with treatment failure of SOF, PegIFN plus RBV in CHC patients.

Additionally, our study found an association between serum AFP, and advanced fibrosis grade with treatment failure. However, Chemerin G/G (rs17173608) genotype and serum chemerin levels showed the highest significance among all the mentioned predictors and our model represented the strongest predictor for treatment failure as widely explored by ROC curve with $77.1 \%$ specificity, $80.2 \%$ sensitivity and $78.9 \%$ accuracy.

Inflammation might have a significant impact on patient response to antiviral therapy especially triple therapy SOF, Peg-IFN plus RBV. This was concluded by relating serum level of chemerin and its genetic polymorphisms rs17173608 in chemerin gene with treatment outcomes in CHC G4 patients. Our model provided a strong predictive, reliable tool for treatment prediction for CHC G4 Egyptian patients.

\section{Conclusions}

Finally, this study concluded that NR to triple therapy in CHC G4 Egyptian patients was associated with remarkable elevated serum IL-6, serum AFP levels, 
chemerin genotypes and increased serum chemerin levels as well as advanced degrees of fibrosis in CHC Egyptian patients. Chemerin G/G (rs17173608) genotype and high serum chemerin levels showed the highest predictive power for failure of SVR in triple SOF, Peg-IFN plus RBV therap. Such approach would save time and cost of therapy for $\mathrm{CHC}$ patients and could help in switching the treatment for some contraindicated patients from triple therapy SOF, Peg-IFN plus RBV to other novel DAAs combinations.

\section{A list of abbreviations used:}

chronic hepatitis $\mathrm{C}$ (CHC), genotype 4 (G4), single nucleotide polymorphisms (SNPs), alfa-fetoprotein (AFP), pegylated interferon (Peg-IFN), sofosbuvir (SOF), ribavirin (RBV), sustained viral response (SVR), area under the receiving operating curve (AUROC), hepatitis $\mathrm{C}$ virus (HCV), direct acting antivirals (DAAs), non-responders (NR), alpha-feto protein (AFP), real time polymerase chain reaction (RT-PCR), enzyme linked immunosorbent assay (ELISA).

\section{Conflict of interests}

The authors declare that there is no conflict of interest that could be perceived as prejudicing the impartiality of the research reported.

\section{Funding}

This research did not receive any specific grant from any funding agency in the public, commercial, or not-for-profit sector.

\section{Acknowledgements}

Authors would like to thank all laboratory team members at Dr. Yassin Abdel Ghaffar center for liver diseases for their aid in technical laboratory analyses.

\section{REFERENCES:}

Ali S.;Ellakwa D.;Emara S. and El-Sabbagh N. (2018): The role of chemerin and vaspin in Egyptian patients with viral hepatitis C. Meta Gene, 18: 23-30.

\section{Bauer S.;Wanninger J.;Schmidhofer S.;Weigert J.;Neumeier M.;Dorn C.;Hellerbrand C.;Zimara N.;Schaffler A.;Aslanidis C. and Buechler C. (2011): Sterol regulatory element-binding protein 2 (SREBP2) activation after excess triglyceride storage induces chemerin in hypertrophic adipocytes. Endocrinology, 152: 26-35.}

Bozaoglu K.;Bolton K.;McMillan J.;Zimmet P.;Jowett J.;Collier G.;Walder K. and Segal D. (2007): Chemerin is a novel adipokine associated with obesity and metabolic syndrome. Endocrinology, 148: 4687-94. 
Cavalcante L. N. and Lyra A. C. (2015): Predictive factors associated with hepatitis C antiviral therapy response. World J Hepatol, 7: 1617-31.

Costantini S.;Capone F.;Guerriero E.;Maio P.;Colonna G. and Castello G. (2010): Serum cytokine levels as putative prognostic markers in the progression of chronic HCV hepatitis to cirrhosis. Eur Cytokine Netw, 21: 251-6.

Desbois A. C. and Cacoub P. (2017): Diabetes mellitus, insulin resistance and hepatitis C virus infection: A contemporary review. World J Gastroenterol, 23: 1697-1711.

El-Mesallamy H. O.;El-Derany M. O. and Hamdy N. M. (2011): Serum omentin-1 and chemerin levels are interrelated in patients with Type 2 diabetes mellitus with or without ischaemic heart disease. Diabet Med, 28: 1194-200.

Fallahi P.;Ferri C.;Ferrari S. M.;Corrado A.;Sansonno D. and Antonelli A. (2012): Cytokines and HCV-Related Disorders. Clinical and Developmental Immunology, 2012: 10.

Gane E. J.;Shiffman M. L.;Etzkorn K.;Morelli G.;Stedman C. A. M.;Davis M. N.;Hinestrosa F.;Dvory-Sobol H.;Huang K. C.;Osinusi A.;McNally J.;Brainard D. M.;McHutchison J. G.;Thompson A. J. and Sulkowski M. S. (2017): Sofosbuvir-velpatasvir with ribavirin for 24 weeks in hepatitis C virus patients previously treated with a direct-acting antiviral regimen. Hepatology, 66: 1083-1089.

Ghany M. G.;Strader D. B.;Thomas D. L. and Seeff L. B. (2009): Diagnosis, management, and treatment of hepatitis C: an update. Hepatology, 49: 1335-74.

Habib S. S.;Eshki A.;AlTassan B.;Fatani D.;Helmi H. and AlSaif S. (2017): Relationship of serum novel adipokine chemerin levels with body composition, insulin resistance, dyslipidemia and diabesity in Saudi women. Eur Rev Med Pharmacol Sci, 21: 1296-1302.

Hart R. and Greaves D. R. (2010): Chemerin contributes to inflammation by promoting macrophage adhesion to VCAM-1 and fibronectin through clustering of VLA-4 and VLA-5. J Immunol, 185: 3728-39.

Heid C. A.;Stevens J.;Livak K. J. and Williams P. M. (1996): Real time quantitative PCR. Genome Res, 6: 986-94.

Imai K.;Takai K.;Hanai T.;Shiraki M.;Suzuki Y.;Hayashi H.;Naiki T.;Nishigaki Y.;Tomita E.;Shimizu M. and Moriwaki H. (2014): Impact of serum chemerin levels on liver functional reserves and platelet counts in patients with hepatocellular carcinoma. Int J Mol Sci, 15: 11294-306.

Kukla M.;Adamek B.;Waluga M.;Zalewska-Ziob M.;Kasperczyk J.;Gabriel A.;Mazur W.;Sobala-Szczygieł B.;Bułdak R. J.;Zajęcki W.;Kępa L.;Ziora 
K.;Żwirska-Korczala K.;Wiczkowski A. and Hartleb M. (2014): Hepatic chemerin and chemokine-like receptor 1 expression in patients with chronic hepatitis C. Biomed Res Int, 2014: 517820-517820.

Ladero J. M.;Martin E. G.;Fernandez C.;Carballo M.;Devesa M. J.;Martinez C.;Suarez A.;Diaz-Rubio M. and Agundez J. A. (2012): Predicting response to therapy in chronic hepatitis C: an approach combining interleukin-28B gene polymorphisms and clinical data. J Gastroenterol Hepatol, 27: 279-85.

Mehanna E. T.;Mesbah N. M.;Ghattas M. H.;Saleh S. M. and Abo-Elmatty D. M. (2016): Association of chemerin Rs 17173608 and vaspin Rs2236242 gene polymorphisms with metabolic syndrome in Egyptian women. Endocr Res, 41: 43-8.

Menezes E. G.;Coelho-Dos-Reis J. G.;Cardoso L. M.;Lopes-Ribeiro A.;JonathanGoncalves J.;Porto Goncalves M. T.;Cambraia R. D.;Soares E. B.;Silva L. D.;Peruhype-Magalhaes V.;Rios M.;Chancey C.;Teixeira-Carvalho A.;Martins-Filho O. A. and Teixeira R. (2017): Strategies for serum chemokine/cytokine assessment as biomarkers of therapeutic response in HCV patients as a prototype to monitor immunotherapy of infectious diseases. Antiviral Res, 141: 19-28.

Moretta A.;Marcenaro E.;Parolini S.;Ferlazzo G. and Moretta L. (2008): NK cells at the interface between innate and adaptive immunity. Cell Death Differ, 15: 226-33.

Roman A. A.;Parlee S. D. and Sinal C. J. (2012): Chemerin: a potential endocrine link between obesity and type 2 diabetes. Endocrine, 42: 243-51.

Stojek M. (2017): The role of chemerin in human disease. Postepy Hig Med Dosw (Online), 71: 110-117.

Tanaka T.;Narazaki M. and Kishimoto T. (2014): IL-6 in inflammation, immunity, and disease. Cold Spring Harbor perspectives in biology, 6: a016295-a016295.

Weigert J.;Neumeier M.;Wanninger J.;Filarsky M.;Bauer S.;Wiest R.;Farkas S.;Scherer M. N.;Schaffler A.;Aslanidis C.;Scholmerich J. and Buechler C. (2010): Systemic chemerin is related to inflammation rather than obesity in type 2 diabetes. Clin Endocrinol (Oxf), 72: 342-8.

Zabel B. A.;Kwitniewski M.;Banas M.;Zabieglo K.;Murzyn K. and Cichy J. (2014): Chemerin regulation and role in host defense. Am J Clin Exp Immunol, 3: $1-19$. 
الكمرين لاغني عنة في التنبؤ بمخرجات العلاج بالسوفوسبوفير والإنترفيرون و الريبافيرين في

ألمرضى المصربين المصابين بالتهاب الكبد الوبائي فيروس (سي)

'مروة عمر عبد العزيز الدريني" و العلياء محمد عبدالجواد سلام؟'

' قسم الكيمياء الحيوية، كلية الصيدلة، جامعة عين شمس، القاهرة، مصر

ץ قسم الكيمياء الحيوية ،كلية الصيدلة و التصنيع الدوائي، جامعة بدر بالقاهرة، مدينة بدر، القاهرة، مصر

الخلفية:

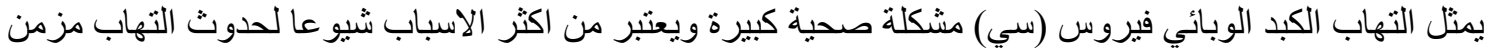

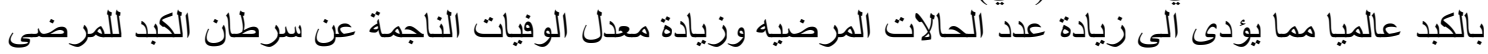

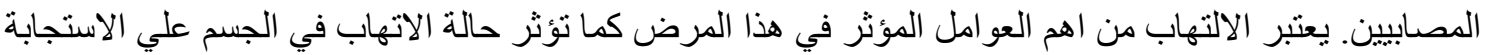

للعلاج.

الهدف من هذه الدر اسة هو:

تحسين مخرجات العلاج الثثلاثي بعقار السوفوسبوفير و الإنترفيرون و الريبافيرين لتجنب الاثار الجانبية الغير

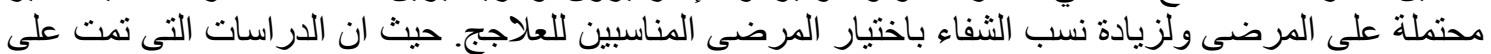

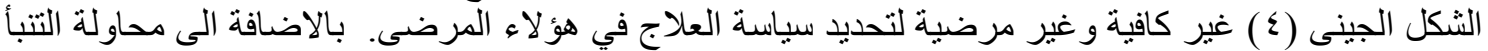

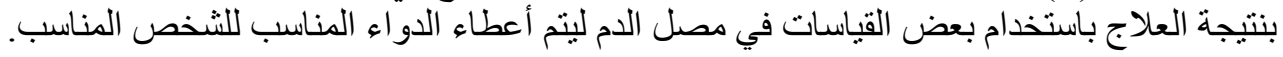

الطرق المستخدمة في البحث:

157مرضى فيروس سى من الجيل الرابع الذين يتناولون العلاج الثثلاثي بعقار السوفوسبوفير و الإنترفيرون

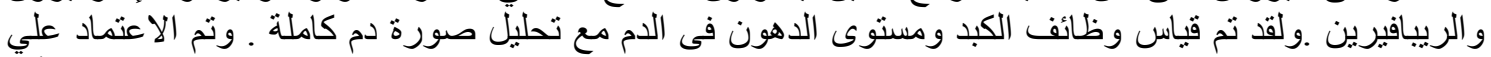
تقنية "معايرة الإنزيم المرتبط الممتز المناعي" لقياس مستوي الانترليوكن 1 و الكمرين و البروتين الجين الجينى ألفا وتحديد النمط الجينى لجين الكمرين.

النتائج:

أكدت الدراسة علي ان ارتفاع مستوى الانترليوكن 7 و الكمرين البروتين الجينى ألفا و الدرجات المتقدمه من تليف

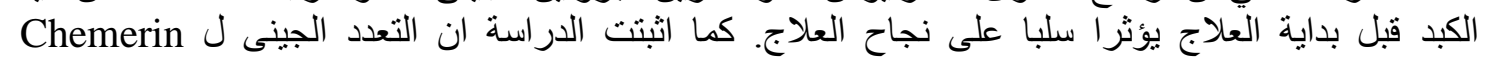

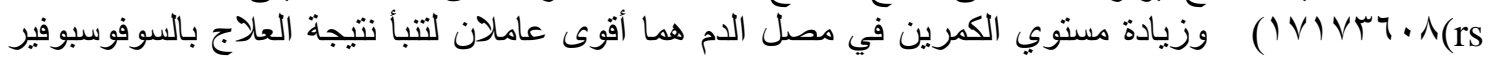

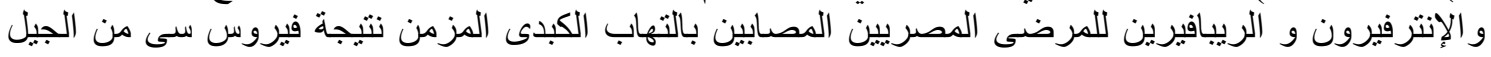
الر ابع.

\section{الملخص:}

اثتتت هذة الدراسة ان الاختلاف فى تعدد الجينات المرتبطة بالالتهاب "الكمرين" لها دور فعال في تحديد نتائج

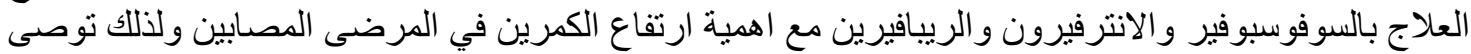

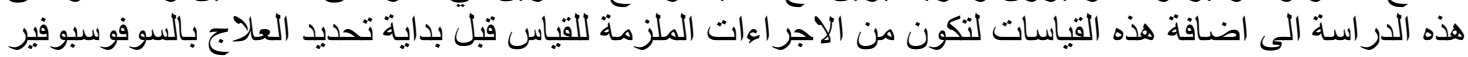

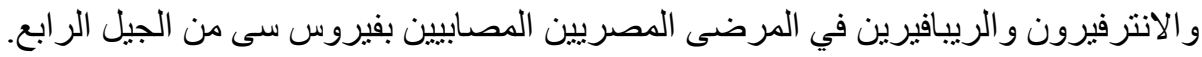

